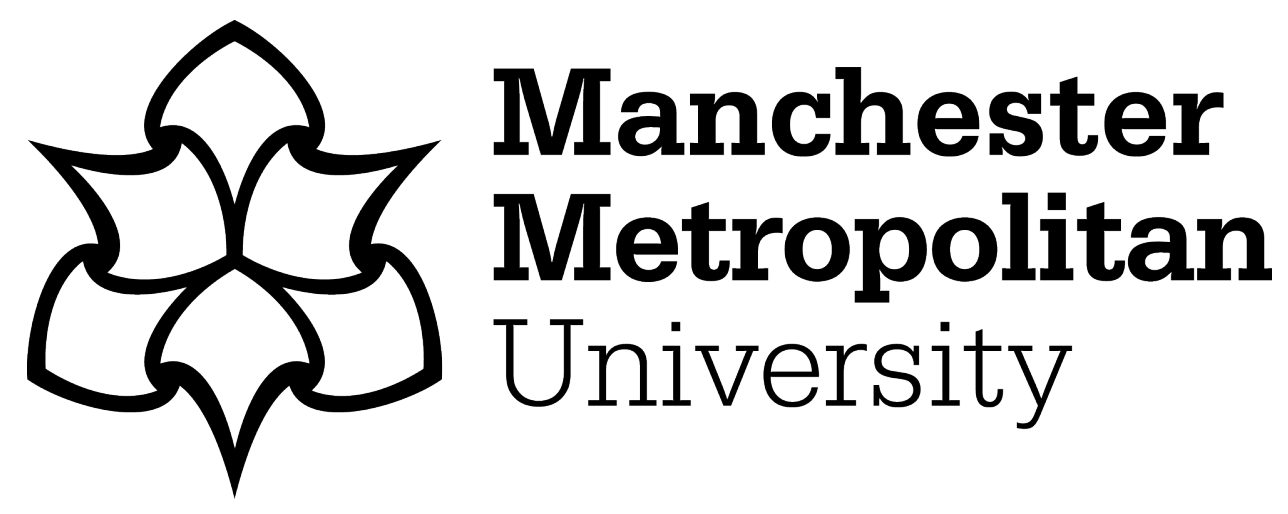

Vanderschelden, I (2016) Money for writing: Screenplay development and screenwriters earnings in French cinema. Studies in French Cinema, 16 (2). pp. 118-133. ISSN 1471-5880

Downloaded from: https://e-space.mmu.ac.uk/618584/

Publisher: Taylor \& Francis (Routledge)

DOI: https://doi.org/10.1080/14715880.2016.1164418

Please cite the published version 


\title{
Money for writing:
}

\section{Screenplay development and screenwriters' earnings in French cinema}

Isabelle Vanderschelden ${ }^{1}$

Department of Languages Information and Communication, Manchester Metropolitan University, 70 Oxford St, Manchester, M1 5NH

\begin{abstract}
The funds allocated to developing screenplays currently constitute on average 2 to $3 \%$ of the overall budget of a film in France. Producers are more than ever dependent on presenting attractive draft screenplays to find their financial partners. As a result, screenwriters undoubtedly are active economic partners of production planning, but they do not seem to receive much professional recognition for this vital role. Moreover, their earnings often fail to reflect the amount of work produced and do not reward adequately the risks taken, including the possibility that production could stop after the screenplay is written.

This article investigates the place of screenplay development within the economics of French cinema. Using recently published official reports and interviews, we identify different types of screenwriters and address their working conditions - freestanding screenwriters, writing teams, and screenwriters co-writing with the director. We survey some of the contract modalities for the remuneration of professional screenwriters. Finally, we review the proposals made by different professional bodies to improve the remuneration of screenwriters and reform the financing of screenwriting.
\end{abstract}

Key words: screenwriting, screenplay funding, writing grants, screenwriters, author royalties.

Screenwriters enjoy variable levels of popularity and professional recognition in France, and their status seems to differ from that of their American counterparts. For example, in the context of Hollywood, the average 'writing package' is estimated to represent eight to ten percent of the overall film budget, ${ }^{1}$ whereas in France, it only amounts to two or three percent. In addition, the proportion of funding allocated to screenplay development has declined between 1980 and $2010 .^{2}$

The underfunding of the writing stage and the income of professional screenwriters for their contribution are sensitive issues. The aim of this article is to clarify the actual place given to screenwriting in the economics of cinema. We will identify different categories of professional authors ${ }^{3}$ writing for cinema, ranging from independent screenwriters commissioned to develop screenplays, to occasional screenwriters, screenwriting directors and regular screenwriting teams. We will give special attention to the frequent model in France, whereby one or several screenwriters are commissioned to help a writing director. Referring, when relevant, to recently published institutional reports on this subject and to interviews addressing the screenwriting process, we will present the main modalities of screenwriters' contracts and some issues that they raise. We will then use this information to review some of the proposals made to improve the recognition of the screenwriters and to reform their remuneration, and the progress made in the last ten years. Our aim is not so much to provide further evidence of the screenwriters' entitlement to better reward for their work, as it features explicitly in all the reports. Rather, we will try to understand the reasons behind a set of economic contradictions that no one denies, but that seem to resist effective reform.

\footnotetext{
${ }^{1}$ i.vanderschelden@mmu.ac.uk
} 
Writing for cinema remains precarious despite the unique funding system operated in France. The actual status of screenwriters is characterised by a certain opacity. The 'Guilde française des scénaristes', the national union of screenwriters founded in 2010, counts about 350 members overall, of which 100 are authors writing exclusively for cinema, and, the rest mainly for television. These rather low figures do not stop more aspiring authors from enrolling every year on the screenwriting programme of the FEMIS ${ }^{4}$ and the proliferation of screenwriting manuals (See Brangé in this volume). The term screenwriter englobes people who adapt existing stories for cinema or write original ones. The most common situation in the French context nowadays is for one (or several) screenwriters to write alongside a director (Kopp 2013). Team screenwriting is mostly reserved for comedy writing or so-called 'producer films', for example Astérix aux jeux Olympiques/Asterix and the Olympic Games (Frédéric Forestier and Thomas Langmann, 2008) and La Famille Bélier (Eric Lartigau, 2014), and in the fast expanding context of television scriptwriting, especially for series and animation. ${ }^{5}$

The sense of insecurity pervading the screenwriting profession englobes identity, legitimacy, recognition and income issues. This situation comes partly from the central position traditionally occupied by French directors and the lasting auteurist trend of French cinema since the New Wave, ${ }^{6}$ which weakened the screenwriter's status (see EscandeGauquié 2012, 88). Until the late 1950s, it was easier to distinguish different types of writing roles assigned to the scriptwriter, the adaptor and the dialogue writer, while the director was not necessarily involved (see Leahy 2015). This distinction is no longer so explicit. While some measures implemented since 2000 have reaffirmed the key-role of screenwriters in the economy of cinema as guarantors of quality for the film, the actual input of individuals is not often defined within writing partnerships. MOREOVER, Screenwriters benefit from limited public visibility and receive little professional recognition, if we except the annual César ceremony. With some exceptions of a few high-profile names, who are often directors themselves, few professional authors can claim today to live exclusively from their screenwriting work for cinema (see Tremblay 2015, 106).

Since 2000, a number of reports have raised the alarm on the chronic underfunding of screenwriting. In a report commissioned by the $\mathrm{CNC}$ on the development of screenplays in French cinema, the producer Charles Gassot acknowledged the underscoring of screenwriters and made 13 recommendations for supporting screenwriting (Gassot 2001). This triggered a series of measures to increase the financial support to the screenwriting process, including changes in the provision of aids of the CNC to enhance the writing stage (see Tremblay 2015, 82-83). Stressing the importance of screenplay development and screenwriters was also a central concern for the Club des 13's pamphlet in 2008, Le Cinéma du milieu n'est plus un pont, c'est une faille. Its working party led by Pascale Ferran identified the situation of the screenwriters as 'unsustainable', and called for urgent reforms, both in terms of cultural perception of status, and a reassessment of economic market forces:

The work of the screenwriter for feature films has never been recognised in France in cultural terms. Consequently, it has never been remunerated in a fair way as though it were seen as depreciating the value of writing and cinema alike, a less noble activity than the work of a writer, and a less classy one than that of a filmmaker. $(2008,36)^{7}$

The Club des 13 regretted that screenwriters were rarely included in a film's commercial and critical success. For example, authors received few invitations to take part in festivals, and their names did not feature prominently on posters. Ferran and al. recommended more effective support mechanisms in the early stages of development of a project and better recognition of the role of screenwriters through royalties. They specifically mentioned the 'cinéma du milieu', namely films which have an overall budget between 3 and $8 \mathrm{M} €$, which 
have been particularly affected by the reduction of writing budgets since 2000 . They denounced the interchangeability of screenwriters, and the use of multiple script-doctors, all of which contributed to weakening their legitimacy. Finally, they alerted to the potential danger of transforming screenwriters into 'storytelling technicians' ('techniciens du récit'), a trend reminiscent of current American practice (2008, 43).

This pamphlet found a significant echo in the professional film circles and the press, and it played an instrumental role in the commissioning of further studies and in the reinforcement of corporate action after 2010. For example, in 2012, the 'Guilde nationale des scénaristes' commissioned the economist Pierre Kopp to collect data on screenwriter remuneration trends and screenwriting practices. His report is based on 561 contracts for 242 films produced between 2010 and 2011 (half the number of films produced in France in these two years). It provides valuable information and conclusions on the funding of the writing stage and the earnings of screenwriters.

The most recent public study on the film industry, however, is producer René Bonnell's report, commissioned by the Minister of Culture and released in December $2013 .{ }^{8}$ It provides detailed accounts of the funding mechanisms of cinema, identifies the important issues that need addressing in each area, including the writing stage. It also makes 50 precise recommendations for improvements and reforms required for the digital era, some of which relate directly to supporting screenwriting and authors' remuneration. Proposals 4 and 5 in particular address the funding of the writing stages (Bonnell 2013, 168) while 48 to 50 suggest that authors should receive fair royalties through more transparent procedures (174).

All the reports published in the last ten years have thus consistently reiterated the issue of the underfunding of writing stage in film production (see Barraco 2013). They have highlighted the precarious conditions in which screenwriters operate and the lack of guaranteed remuneration. In the early stages of development, screenwriters have difficulty in negotiating upfront payment for their work. They obtain limited advances without real guarantee of the full payment of the sums agreed in their contracts. The reports also stressed the need for more transparency in the payment of royalties. In order to understand this complex situation, we need to gain a better understanding of the practices of screenwriting for cinema, identifying the different stages of screenplay development before the film is made ('la fabrication'), but also the trends in terms of contracts and copyrights for authors.

\section{The writing development process for films}

Screenwriting involves multiple drafts and different players. Screenwriters who are not directors can approach a producer with their idea or be asked to provide the screenplay of an adaptation or an original idea by a producer and/or director. Knowing that many ideas (and projects going into preproduction) will never become films, the parties involved in funding the development, and this often includes film distributors as well as producers, directors and screenwriters, take a calculated risk based on trust and professional experience. Producers need a convincing screenplay outline (treatment) to support their funding applications, and to secure financial partnerships with distribution companies and television channels whose participation is, or at least was until recently, deemed crucial to any project's viability. ${ }^{9}$ Unless the screenwriter is an established filmmaker planning to direct, it is difficult for $\mathrm{him} /$ her to look for the funding independently, which explains the close relationships that develop between authors, filmmakers and producers. As a result, they normally team up in the early stages and work closely together, often remaining long-term partners across several projects.

The first treatment is a provisional text, in a format that can vary from a few pages to a full plot outline, acting as the stepping-stone for any creative project to obtain funding. The 
impression made is crucial, as it needs to attract the attention of selection panels primarily composed of producers, critics, authors, and actors. This early draft typically provides a plot outline, introduces the characters and the narrative point of view, as well as indications on genre and style conventions that define the future film. The next stage consists of working on successive drafts leading to a full, typed screenplay delivered to the producer, which will be transformed into a continuity script including the sequencing and dialogue ('le découpage') for use during shooting.

The full development process, which involves substantial research and collaborative work, can span over a period of two years (this is the maximum period of validity of CNC grants), but often exceeds this limit in practice. For example, for Camille redouble/Camille Rewinds (Noémie Lvovsky, 2012), the co-writers listed in the credits, were brought into the project at different stages by the screenwriter-director Lvovsky as she reworked numerous drafts of the screenplay over a period of two years (Boussageon 2012). If several successive screenwriters are called upon, it is not unusual for the development to be interrupted for several years, as was the case for Un prophète/A Prophet (Jacques Audiard, 2009) which took seven years to produce and has a complex history of successive drafts with different authors. ${ }^{10}$

The genesis of a successful recent comedy that sold 7.5 million tickets in France, $L a$ Famille Bélier, provides a telling story of the transitory status of the screenplay and the role played by successive screenwriters. It also illustrates the long journey from an initial pitch and prospective first draft to a finished continuity screenplay used for the shooting, to obtain the film shown in cinemas. In this case, unlike what had happened for Camille redouble or Un prophète for which the directors were also the project initiators, the person chosen by the producer to direct the film had not taken part in the initial screenplay development. First-time screenwriter Victoria Bedos had provided independent producers Stéphanie Bermann and Éric Jehelmann with a pitch inspired by her personal experience and a first draft informally co-written with a friend, Stanislas Carré de Malberg. Only then did the producers approach Lartigau to direct the film. He wrote a new version of the screenplay with experienced screenwriter Thomas Bidegain. The film is the outcome of these successive interventions, and the director's standpoint is revealing on the power relations at play between screenwriters and directors:

The script is one part of the film creation process. It's a tool, nothing more. Each stage is different. I immediately sensed that we would not be able to work together because Victoria [Bedos] had come to a stop with this project. With her co-writer, they felt they had done all they could. Whenever I suggested anything, they rejected it. In one of our meetings, I told them that I was taking the script away because I had a film to make. That's life... Victoria was surprised because it was the first script she had written and she did not know how it worked. You need to know that most of the time, directors do not consult the screenwriters before they film. (in Narbonne 2014).

As this example suggests, the director can influence the development as much as the producer, not just in the context of auteur cinema when the filmmaker is the initiator of the idea. The genesis of La Famille Bélier confirms the collective nature of script development, often a team, led by the producer, with director and author(s). To complete our overview, we now need to scrutinise to what extent the screenwriting process is conditioned by successful applications for selective funding from the different commissions.

The French model underlying the funding of films rests upon pre-financing rather than on the commercial exploitation of the film (see Editorial introduction). The established policies of automatic and selective grants encourage producers and directors to apply to the different grant commissions, starting with the 'avance sur recettes' (advance against earnings) 
run by the Centre national du cinéma et de l'image animée (CNC). These grants are destined to the production process, not just to the writing stage, although the post-2000 successive reforms aim to promote aids to the different stages of the development. Out of 800 to 1,000 films projects presented each year to the financing institutions, between 200 and 250 receive support (Alexandre 2015, 142). In 2010, the various CNC commissions allocated 25M€ thus helping about 60 films, a third of which were first films (212). The amount allocated increased by 4\% between 2013 and 2014 (CNC 2015, 7).

The selective grants include writing aids ('Aide à l'écriture') to get projects off the ground; development aids ('Aide au développement'), which support the development of promising existing drafts into full screenplays ready for shooting; and rewriting aids ('Aide à la réécriture'), designed to improve existing promising drafts. The commissions apply specific criteria, including evidence of prior experience (for screenwriters and directors), and of activity (for production companies). This final consideration is significant, as Alexandre's research on production companies in France shows that many companies are referenced, but currently inactive $(2015,113)$. The commissions also differentiate between first films and projects by experienced filmmakers. The third CNC commission is exclusively for grants attributed retrospectively to films that are already completed and released. All grants are in theory repayable, if a film becomes profitable, however, recent statistical evidence suggests that only around 10 percent of French films are profitable (Legras 2014; see also Kopp 2013). In this unique funding model to encourage French film production, screenwriters therefore represent active partners for producers and directors during the (pre)production stages, but their professional recognition and their remuneration does not seem to match this crucial role in the partnership.

\section{Screenwriters earnings: a verdict of chronic underfunding}

According to the model contracts available on the website of the Guilde des scénaristes, screenwriters can obtain income from three main different sources at different stages of development, if the film goes into production. The first payment, known as 'minimum garanti' (MG), guaranteed minimum or 'front end' in English, is usually provided by the distributor. It forms the basis of future royalties agreed in the contract, and acts as a negotiated partial advance. They receive the final instalment of the MG, negotiated with the producer, only once shooting starts. If a project aborts in the late stages of pre-production, which, worryingly, has increasingly happened in the last ten years, screenwriters can lose 25 to $50 \%$ of the amount agreed in their contract. ${ }^{11}$ The MG normally remains under $1 \%$ of the overall budget according Kopp's findings, with 50\% of French films having a budget of under 5.5M€ $(2013,5)$. Screenwriters' agents and the Guilde nationale des scénaristes propose that the MG be systematically indexed during the evolution of the film's budget, but this type of adjustment is still exceptional (see de Sacy's interview in this volume). This would ensure that the screenwriter is not penalised in case of discrepancies between the anticipated budget used as reference when signing the contract and the final budget granted to the film.

The second source of income consists of a bonus added during the commercialisation, once the film reaches a certain level of tickets sales, (also called in English the 'back end'). In 2010-2011, 24\% of the screenwriters contacted by Kopp had experienced this type of ad-hoc arrangement in their contracts. ${ }^{12}$ The final form of income takes the form of rights due on the commercial returns of the film. This normally comes from the 'producer's share of net earnings' known in France as RNPP. ${ }^{13}$ The RNPP corresponds to the total receipts after tax from the film's commercialisation worldwide, not just in cinemas, which should theoretically 
reward the screenwriter(s) in proportion to the commercial success of the film. In 2011, a study conducted by the SACD (Société des auteurs et compositeurs dramatiques) on the remuneration of film authors ${ }^{14}$ highlighted the lack of transparency of the process and demonstrated that it takes a large number of cinema tickets sold to just reach the amount paid as guaranteed minimum on submission of the manuscript (see Dechesne 2011). According to Kopp, $66 \%$ of film authors try to have this proportional remuneration included into their contracts, but screenwriters tend to receive a smaller proportion than writing directors, namely $0.76 \%$ on average as opposed to $3.48 \%$ (Kopp 2013, 29). Even for commercial successes, screenwriters' royalties are not systematically indexed to box-office results. What is more, the prestige associated with the critical success of a film, through professional awards and positive critical reception, for instance, seldom translate into concrete extra financial rewards for the authors.

As Agnès de Sacy has noted, 'the object around which a film is economically and, in part, artistically constructed is under-valued' (in Sabate 2013). This is by no means a new situation (see for example, Raynauld 1991, 22). The demise of screenwriters goes back several decades to the New Wave and the dominance of the auteur-director over the screenwriter in the French film industry. ${ }^{15}$ This transformed the production of films, promoting mise-en-scène over screenplay, especially for lower budget art cinema. Fifty years on, the undervaluation of the screenwriters' work remains an issue, exacerbated by other structural changes in the national film economy as a special dossier of the Cahiers du cinéma recently confirmed (see Delorme 2015; Béghin and al. 2015). As television channels became key financial partners in film production from the 1980s, they played a greater role in the evolution of screenwriting format. While it is clear that they provided substantial funds to produce French films, they also imposed more standardisation. ${ }^{16}$ Yet, the financial role of television is in the process of changing again in the light of recent developments in the distribution, broadcasting with the increased consumption of cinema on new digital supports. As a result, France produces more films than ever, but paradoxically, more film projects than ever are abandoned at advanced stages of writing and production, mostly due to the collapse of their financial plan. ${ }^{17}$

In the last ten years, a number of press articles (e.g. Carrière 2008, Cottet 2013, Klomp 2013) have reported the difficulties of screenwriters to make a living from their work. In December 2012, Vincent Maraval's explosive article on the excessively generous contracts for French film stars in Le Monde started a polemical debate (see Nacache in this volume). This in turn triggered related articles and responses in 2013 on the relatively poor remuneration of screenwriters, in comparison with some actors, high-profile auteur-directors and producers of commercial films (see for example Raynaud 2013; Klomp 2013). Meanwhile, screenwriters participated actively in the negotiations around the new collective agreements for the film profession salaries ('conventions collectives'). They were, however, less directly involved in the reforms of the status of occasional workers of the entertainment industry ('intermittents du spectacle'), as this social scheme providing unemployment benefits for artists and technicians when they are not under contract is not open to screenwriters.

Even though the screenwriter's role is becoming better acknowledged again and that specific mechanisms are now officially in place to promote the development of the screenplay, it is understandable that authors writing for cinema should strive to increase their guarantees of fair payment. From the reports mentioned above, three specific points have been identified which are directly relevant to the discussion around the undervaluation of the work of the screenwriter: the types of working partnership in screenwriting; the nature of the collaborative work of screenwriters and directors; and finally, the economic impact of writing collaborations. Only a small proportion of French films are written by a sole specialist 
screenwriter, who is not also the director. Kopp's sample shows that only $9 \%$ had an independent screenwriter, while $32 \%$ were scripted by their director alone, and $59 \%$ by the director with one or more collaborators. In other words, $91 \%$ of directors contributed to the development of their scripts and were credited for this (Kopp 2013, 5). Camille Haddouf's complementary study on the place of women writing for French cinema between 2003 and 2012 (Haddouf and Wolgust 2014) reaffirms this situation. This entails underlying relations of power, which can place screenwriters in a vulnerable position. Tremblay's findings confirm, for example, that screenwriters often hesitate to claim their royalties as too much insistence might prevent them from working again with the same producer or director in future (Tremblay 2015, 108-9).

Many screenwriters are part of recurrent writing teams, such as Thomas Bidegain's partnership with Jacques Audiard, Laurent Cantet with Robin Campillo, Guillaume Laurent with Jean-Pierre Jeunet, Agnès de Sacy with Valeria Bruni Tedeschi, and Florence Seyvos with Noémie Lvovsky. The example of Camille redouble reveals how a writing partnership fundamentally serves a director's project. Lvovsky, an author who usually writes her own screenplays with Seyvos, had the initial idea. She first secured some help from Maud Ameline, a FEMIS graduate, then from a regular co-writer of her films, Pierre-Olivier Mattei who offered informal advice. Yet, Lvovsky ended up returning to Seyvos, who reworked the script. The three co-authors never actually worked together, they pitched in at different stages of the development to help the filmmaker's project (in Mével 2012, 74-75). They were 'accompanying' her in her writing, 'working in her territory, on her artistic creation project to borrow an expression that de Sacy uses to describe her own collaboration with Pascal Bonitzer. ${ }^{18}$ Bidegain too envisages his contribution to Audiard's films as a relation of 'complementarity' based upon common artistic ground. While he feels listened to and respected, he admits that he is working on the director's project, and implicitly plays down his own screenwriting role suggesting that in the end, as screenwriter, he is contributing to writing Audiard's film, and that he [Audiard] has the last say' and controls the screenplay (Bidegain in Labbas 2012). At best, the practice of recurrent collaboration fosters close partnerships based on mutual respect. In some cases however, the collaborator's role can be downplayed to the point of masking screenwriter visibility.

Co-writing practices affect the screenwriters' earnings, of course, but also their legitimacy, which indirectly has consequences on their professional status. The higher the number of screenwriters involved in the development, the more fragmented the writing contracts become for each contributor, as well as their ownership of intellectual property. As they are credited and receive separate contract for their role as (co)-screenwriters and as directors, writing directors receive more income and credit for the development of screenplays, especially for successful commercial films such as comedies. Comedy writers can even become recognised as 'bankable' in the French system, as the cases of screenwriterdirectors such as Francis Veber and Dany Boon illustrate. Veber earned around 2.5M€ per film in the 2000s (Carrière 2008), and following the success of Bienvenue chez les Ch'tis/ Welcome to the Sticks (2008), Boon received (or should we say allocated himself, as he was also the producer of the film) 3.5M€ for Rien à déclarer/Nothing to Declare (2010) and Superchondriaque (2013). He occupied the top place of the best-paid actor-director list in the $2010 \mathrm{~s}^{19}$, and this was commented upon with the help of Maraval's article, for example, placing him in the centre of the debate around possible dysfunctions in the financing of French cinema.

Kopp's report did not make any distinction between filmmakers who write their films and screenwriters who become the directors of their own scripts after writing screenplays for others. However, this further subcategory of author deserves some attention, in view of the 
number of active screenwriters who have started directing the films that they wrote in the last ten years. No precise extra statistical data is available to confirm this trend, but recent examples of transfer of roles abound, often with screenwriters who have acquired a certain visibility. Robin Campillo, an IDHEC graduate, has written regularly with Laurent Cantet and co-edited his films, including L'Emploi du Temps/Time Out (Laurent Cantet, 2001) and Entre les Murs/ The Class (Laurent Cantet, 2008) and Foxfire (Laurent Cantet, 2012). He directed his first feature film, Les Revenants/The Returned in 2004, followed by Eastern Boys in 2014. ${ }^{20}$ Campillo therefore combines several professional hats, as screenwriter, editor and director, even if he continues to work as a screenwriter for others, Planetarium (Rebecca Zlotowski, 2016 still in postproduction at the time of writing) or as a script consultant for example for Maryland/Disorder (Alice Winocour, 2015). It is striking to see how he projects himself in interviews, as a filmmaker rather than as a screenwriter making films: 'I am not fascinated by the script as object. If we could do without it, I would be just as happy. [...] Film people think that fiction is all about a screenplay' (in Feuillère 2006). This suggests that Campillo sees himself as a filmmaker more than a screenwriter and it illustrate a recurrent aspiration that consist of using screenwriting as a stepping stone to filmmaking. (see Lefort and Ghys 2014)

Another example of successful transition is the career of Thomas Bidegain who, after co-writing several high-profile films with Jacques Audiard, made his directing debut with Les Cowboys in 2015 for which he produced the original idea and was co-screenwriter. This film, produced by Alain Attal, was co-written with Noé Debré with whom Bidegain had also worked as screenwriter on Un prophète and Deephan (Jacques Audiard, 2015). He had also acted as co-screenwriter for other directors' films, including Saint-Laurent (Bertrand Bonello, 2014). These examples highlight the importance of professional networking and collaborations in the development of the screenwriter's professional reputation and access to visibility. Career development, finding new screenwriting commissions or moving to filmmaking is conditional to establishing contacts and making a name within the profession regardless of talent and training (see Bidegain in Labbas 2012). There also seems to be a direct correlation between successful collaborations with high profile filmmakers and the opportunity for screenwriters to direct their first film, usually with the help of the same producer or with financial partners with whom they have had professional contracts previously.

The economic position of screenwriters remains unstable despite recent debates raising their visibility and the increase in public awareness of their role in filmmaking. The structures of the French film industry and the complex financial packages upon which production relies today partly explain why many directors control the writing process, while many screenwriters aspire to directing to retain more authority over their work. However, those who specialise as screenwriters still struggle to obtain fair advances for their work and have even more difficulty receiving owed royalties after the commercialisation of the films.

\section{Evaluating the screenwriters' access to recognition and fairer remuneration}

Since Gassot's report in 2001, concrete measures to revalorise the development of screenplays have been implemented, changing some of the conditions of support to screenwriters, and prioritising screenwriting and creativity in the guidelines for film accreditation by the CNC (Tremblay 2015, 82-3). In 2003, the CNC started revising its programme of grant allocation, placing more emphasis on script development, and explicitly recognising the need for extra support during the early stages of writing, with a maximum grant of $30000 €$ per application, or $20000 €$ for any individual author (Bredin 2013). These changes have probably helped to complete financial packages, but there is little evidence that 
they have served directly to pay the screenwriters better advances for the early stages of the writing process, or that they have increased their actual income. The CNC's programme has also created specific funding schemes (see Tremblay 2015, 83-87). For example, concrete support is now available rewriting and screenplay improvements after feedback on initial drafts is under progress.

Some screenwriters have embraced the advice given by the Club des 13 in 2008 to establish close partnerships with authors' unions and the SACD. Following the creation of the Guilde nationale des scénaristes, screenwriters and producers have signed several protocols of transparency clarifying remuneration mechanisms in 2010 and 2012. ${ }^{21}$ They have teamed up with the 'Société des auteurs audiovisuels' (SAA) which is specifically in charge of monitoring the distribution and collection of authors' rights 'represent[ing] the interests of authors, particularly screenwriters and directors of films' ${ }^{22}$ With the Guilde nationale des scénaristes, they have developed a set of targeted proposals in 2013, based on Kopp's report in order to increase the protection of the screenwritier's professional status (Barroco 2013). All partners are now working together to establish a policy for online copyrights and the creation of collective management groups for the collection and redistribution of royalties.

The recommendation to reserve $7.5 \%$ of the French film fund to script development to attract talented screenwriters and create a 'pool of professionals capable of providing popular, innovative and original screenplays' will take longer to implement (see Club des 132008 , 288, 295-297). At the time of writing, only slow progress is perceptible on this point in the CNC's reports. Bonnell noted some changes in the protection of the artistic rights of cinema authors, and a more favourable attitude towards revaluing writing costs - they have nearly doubled in the last ten years, rising from $2.7 \%$ to $4.3 \%$ of total costs (Bonnell 2013, 25). Moreover, screenwriter contracts have adopted more specific norms, as shown by the protocol of December 2012. In practice however, these measures only bring limited protection of the professional screenwriter's author rights and income. They do little to separate the roles of screenwriting and film directing which could lead to a separate qualitative evaluation of film projects. Consequently, it is still tempting for French directors to opt to do without the expertise and talent of a specialist screenwriter in preproduction. In addition, the limited protection of screenwriters' artistic rights over their text once the screenplay is delivered discourages some authors to enter into partnership with a director to produce a better film. They therefore try to direct themselves, which is understandable, but does little to reaffirm the professional identity of the screenwriter.

If the Protocols of 2010 and 2012 constitute important steps towards reforming the screenwriters' social rights, the authors' unions agree that the support provided remains insufficient. Negotiations over contracts continue to take place on an individual basis, which encourages power games with producers (and sometimes directors). For example, to our knowledge, there is still no legal obligation to remunerate the initial phase of the screenplay development, even though this early funding could come directly from grants such as the CNC's. This is why the Guilde nationale des scénaristes has recently proposed to ring-fence the funds allocated for screenwriting, and now insists that screenwriters request that the development remuneration be explicitly included in their contracts (see de Sacy's interview in this volume).

In conclusion, the national film institutions have acknowledged the importance of granting fairer remuneration and status to screenwriters. They work, each in their own ways, to defend the rights of screenwriters, promote screenplay development and encourage transparency of remuneration. The successive protocols to improve contracts in the last five years and the collective agreements of 2013 represent steps in the right direction. Further measures are under negotiation at the time of writing, involving broader political reforms within the cultural sphere, such as agreements on employment statuses and pensions. The 
different parties have recognised the crucial role of screenwriters in a healthy national film industry. They still need to action substantial corrections of the undervaluing of their contribution.

\section{Notes on contributor}

Isabelle Vanderschelden is Senior Lecturer and French Section Lead in the Department of Languages, information and communication at Manchester Metropolitan University. She has published many articles on different aspects of Contemporary French cinema. Her books include a Film study guide on Amelie (IB Tauris 2007), and Studying French Cinema (Auteur 2013). She has coedited with Darren Waldron France at the Flicks: Issues in Popular French Cinema (Cambridge Scholars Publishing 2007), and is currently working on a book on French screenwriters with Sarah Leahy to be published by Manchester University Press. She is co-founder of FILTA (Film in Teaching Association) a website and network promoting the use of film in language classes.

\section{Filmography}

Astérix aux jeux Olympiques, 2008, Frédéric and Forestier Thomas Langmann, France/Italy/ Germany/Spain, screenplay Thomas Langmann, Olivier Dazat, Franck Magnier and Alexandre Charlot.

Bienvenue chez les Ch'tis, 2008, Dany Boon, France, screenplay Dany Boon, Franck Magnier and Alexandre Charlot.

Boule et Bill, 2013, Franck Magnier and Alexandre Charlot, France, screenplay Franck Magnier and Alexandre Charlot.

Camille redouble, 2012, Noémie Lvovsky, France, screenplay Maud Ameline Pierre Olivier Mattei, Florence Seyvos and Noémie Lvovsky.

Château en Italie, 2013, Valeria Bruni Tedeschi France/Italy, screenplay Noémie Lvovsky, Agnès de Sacy and Valeria Bruni Tedeschi.

Cherchez Hortense, 2010, Pascal Bonitzer, France, screenplay Agnès de Sacy and Pascal Bonitzer. Cowboys (Les), 2015, Thomas Bidegain, France, screenplay Noé Debré, Thomas Bidegain.

Deephan, 2015, Jacques Audiard, France, screenplay Noé Debré, Thomas Bidegain and Jacques Audiard.

De rouille et d'os 2012, Jacques Audiard, France, screenplay Thomas Bidegain and Jacques Audiard.

Emploi du Temps, (L'). 2001. Laurent Cantet. France, screenplay Robin Campillo and Laurent Cantet.

Entre les murs, 2008, Laurent Cantet, France, screenplay Laurent Cantet, Robin Campillo and François Bégaudeau.

Eastern Boys, 2013, Robin Campillo, France, screenplay Robin Campillo and Gilles Marchand. Famille Bélier, La, 2014, Eric Lartigau, France, screenplay Victoria Bedos, Stanislas Carré de Malberg, Thomas Bidegain.

Foxfire, 2012, Laurent Cantet, France/Canada, screenplay Laurent Cantet and Robin Campillo. Maryland/Disorder, 2015, Alice Winocour, France, screenplay Alice Winocour and Jean-Stéphane Bron, with Romain Campillo and Vincent Poymiro as script consultants.

Planetarium. 2016, Rebecca Zlotowski, France, screenplay Robin Campillo, Rebecca Zlotowski. Qu'est-ce qu'on a fait au bon Dieu? 2014, Philippe de Chauveron, France, screenplay Philippe de Chauveron and Guy Laurent.

Revenants, (Les), 2004, Robin Campillo, France, screenplay Robin Campillo and Brigitte Tijou. Rien à déclarer, 2010, Dany Boon, France/Belgium, screenplay Dany Boon, Yael Boon. 
Saint-Laurent, 2014, Bertrand Bonello, France/Belgium, screenplay Bertrand Bonello and thomas Bidegain.

Superchondriaque, 2013, Dany Boon, France/Belgium, screenplay Dany Boon.

Un Prophète, 2009, Jacques Audiard, France, screenplay Raouf Dafri, Thomas Bidegain and Jacques Audiard.

\section{References}

Alexandre, Olivier. 2015. La Règle de l'exception : Écologie du cinéma français. Paris : EHESS.

Barraco, Marie. 2013. "Communiqué de presse Guilde des scénaristes.” 7 January.

http://www.guildedesscenaristes.org/uploads/presse/communiques/cp_guilde_rapport\%20rem uneration\%20auteurs\%20cinema.pdf, accessed 12 January 2014.

Béghin, Cyril, Stéphane Delorme, Nicolas Elliott, Florent Guézengar Joachim Lepastier, Louis Seguin, Jean-Philippe Tessé and Laura Tuillier. 2015. "Comment écrire un scénario : Anti-manuel." Cahiers du cinéma. April, 6-30.

Bonnell, René. 2008. "Rapport de M. René Bonnell à la directrice générale du CNC. Le droit des auteurs dans le domaine cinématographique : coûts, recettes et transparence." December 2008, http://www.guildedesscenaristes.org/uploads/ressbao/rapportsetudes/Rapport\%20Bonnell.pdf, accessed 1 February 2013.

Bonnell, René. 2013. "Le financement de la production et de la distribution cinématographiques à l'heure du numérique ", December, http://www.youscribe.com/catalogue/tous/ressources-professionnelles/analyses-etetudes-sectorielles/le-rapport-bonnell-le-financement-de-la-production-et-de-la2380086, accessed 1 February 2013.

Boussageon, Alexandre. 2012. "Camille redouble : double dames : entretien croisé LvovskySeyvos." Le nouvel Observateur. 13 September.

http://tempsreel.nouvelobs.com/cinema/20120913. CIN7354/camille-redouble-doubledames.html, accessed 5 July 2014.

Bredin, Frédérique. 2013. "Le chaînon de l'écriture doit être mieux marqué." 28 November, http://www.sacd.fr/Frederique-Bredin-Le-chainon-de-l-ecriture-doit-etre-mieuxmarque.3621.0.html, accessed 3 February 2015.

Carrière, Christophe. 2008. "Scénariste un métier dans l'ombre." L'Express, 26 November.

Chevalier, Pierre, Franck Philippon and Sylvie Pialat. 2011. "Fiction française : Le défi de l'écriture et de développement." Rapport de la mission Chevalier. March, http://guildedesscenaristes.org/uploads/ressbao/rapportsetudes/Rapport\%20Chevalier.pdf, accessed 2 March 2013.

Club des treize. 2008. Le Milieu n'est plus un pont mais une faille. Paris: Stock.

Cottet, Guilhem. 2013. "Pourquoi le scénariste, pilier du film, est l'éternel oublié du cinéma français." Le Nouvel Observateur, 17 June.

Dechesne, Jérome. 2011. "Jérôme Dechesne présente l'étude SACD sur les contrats d'auteurs dans les longs-métrages". http://www.dailymotion.com/video/xipvjx jerome-dechesnepresente-1-etude-sacd-sur-les-contrats-d-auteurs-dans-les-longs-metrages_news, accessed 25 May 2015.

Desplanques, Erwan \& Hélène Marzolf. 2015. "Séries: les scénaristes français voudraient se lâcher, mais..." Télérama. 30 June, www.television.telerama.fr/television/lesscenaristes-francais-voudraient-se-lacher-mais,128494.php., accessed 17 July 2015.

Despringre, Cécile \& Suzanne Dormer. 2011. "Droits et rémunération des auteurs audiovisuels en Europe." Livre blanc de la SAA. [2015] also available in English 
http://www.saa-authors.eu/dbfiles/mfile/7500/7566/SAA_White_Paper 2015.pdf, accessed on 21 August 2015.

Escande-Gauquié, Pauline. 2012. Pour en finir avec la crise du cinéma français: le cinéma français crève l'écran. Paris: Atlande.

Feuillère, Anne. 2006. "Des battements de fiction : Interview avec Robin Campillo." Cineeuropa website, 22 January, http://cineuropa.org/ff.aspx?t=ffocusinterview \&l=fr\&tid=1183\&did=61737, accessed 2 October 2015.

Ganne, Valérie and Serge Siritzsky. 2014. "French Market Toolkit." Ecran total, Cannes 2014.http://www.guildedesscenaristes.org/uploads/presse/revues/dossier_ecriture ecran total cannes.pdf accessed 21 June 2015.

Gassot, Charles. 2001. "Rapport sur le développement et l'écriture des longs métrages." CNC website. http://www.cnc.fr//, accessed 5 February 2014.

Guilde nationale des scénaristes Website http://www.guildedesscenaristes.org

Haddouf, Camille and Wolgust Isabelle. 2014. "La place des femmes parmi les auteurs écrivants dans le cinéma français sur 10 ans (2003-2012).” May, http://www.guildedesscenaristes.org/uploads/ressbao/rapports-etudes/etude guilde parite cinema.pdf, accessed 26 June 2014.

Jeancolas, Jean-Pierre, Meusy Jean Jacques, and Vincent Pinel. 1996. L'Auteur du film : Description d'un combat. Paris: Institut Lumière.

Klomp, Corinne. 2013. "Les scénaristes sont mal payés quand ils le sont." Médiapart. Website, 6 January, http://blogs.mediapart.fr/blog/corinne-klomp/060113/lesscenaristes-francais-sont-mal-payes-quand-ils-le-sont, accessed 2 June 2014.

Kopp, Pierre. 2013. "La rémunération des auteurs écrivant dans le cinéma de fiction en France (2010-2011).” Guilde nationale des scénaristes website, January. http://www.guildedesscenaristes.org/uploads/ressbao/rapportsetudes/etude guilde cinema.pdf. Also available in English translation http://www.guildedesscenaristes.org/uploads/ressbao/rapportsetudes/cinema guilde kopp report english.pdf, accessed 24 January 2014.

Labbas, Assia. 2012. "Bidegain: Interview : un bon scénariste c'est quelqu'un qui réécrit". Bondyblog website, http://www.bondyblog.fr/201211261301/thomas-bidegain$\%$ c2\%ab-un-bon-scenariste-ce-n $\%$ e $2 \% 80 \% 99$ est-pas-une-personne-qui-ecrit-bienmais-une-personne-qui-reecrit-bien- $\% \mathrm{c} 2 \% \mathrm{bb} /$, consulté le 12 janvier 2014.

Leahy, Sarah. 2015. "Screenwriters in post-war cinema: an overview." Studies in French Cinema, 15, 1, March, 11-37.

Lefort, Gérard and Clément Ghys. 2014. "Robin Campillo: je me suis surpris à filmer mon propre malaise." Libération. 1 April.

Legras, Sophie. 2014. "Cinéma français : 90\% des films ne sont pas rentables." Le Figaro. 8 January. http://www.lefigaro.fr/cinema/2014/01/08/03002-20140108ARTFIG0042990-des-films-francais-ne-sont-pas-rentables.php, accessed 12 October 2015.

Lutaud, Léna. 2013. "Le palmarès des acteurs 2013 : Dany Boon n¹." Le Figaro, 18 February.

Maraval, Vincent. 2012. "Les acteurs français sont trop payés.” Le Monde, 28 December.

Mével, Quentin. 2012. Le cinéma de Noémie Lvovsky. Paris : Independencia.

Narbonne, Christophe. 2014. "Interview avec Eric Lartigau: avec la famille Bélier, j'ai su que j'avais réalisé un bon film.” Première, 454, December 2014.

Raynaud, Manuel. 2013. 'Les scénaristes français sont-ils sous-payés' 19 January. Arte website http://www.arte.tv/sites/fr/dimension-series/2013/01/19/les-scenaristesfrancais-sont-ils-sous-payes/, accessed 23 July 2014. 
Raynauld, Isabelle. 1991. "Le scénario a toujours été en crise." CinémAction, L'enseignement du scénario. 61, 22-27.

SAA Website Société des Auteurs Audiovisuels. http://www.SAA-auteurs.eu

Sabaté, Marc-Antoine. 2013. "Entretien avec Agnès de Sacy: L’écriture du scénario : l'élégance d'un objet de passage." Profondeur de champ website. 25 April. http://profondeurdechamps.com/2013/04/24/rencontre-avec-agnes-de-sacy-12/ accessed 21 September 2014.

SACD Website. Société des auteurs et compositeurs dramatiques. http://www.sacd.fr Tremblay, Gabrielle. 2015. Scénario et scénariste: de la reconnaissance institutionnelle de l'objet scénaristique dans le monde de l'art cinématographique français. La Madeleine (France): Lettmotif.

Vanderschelden, I., 2009. The "Cinéma du milieu is falling down: New challenges for auteur and independent French cinema in the 2000s." Studies in French Cinema 9 (3): 243257.

\footnotetext{
${ }^{1}$ The screenwriters' rights are more protected in America than in France. Union membership is compulsory. The Writer's Guild of America is powerful: in 2001, strike action resulted in new rights and agreements for creators of screenplays, e.g. re-acquiring the rights of their unproduced screenplays, the right to attend cast readings and to visit sets. American screenwriters often co-produce the films they write.

${ }^{2}$ The sample survey used in Kopp's report shows that on average, the writing accounts for $3.3 \%$ (about $230000 €$ ) of total budget. For $50 \%$ of films, it falls under $2.5 \%$ (about $125000 €$ ). (Kopp 2013, 7)

${ }^{3}$ After careful consideration, we chose to make a distinction between the term 'author' in the sense of creative writer operating in a professional context (here screenwriting), and that of 'screenwriter' for the sub-category of author of screenplays. 'Author' therefore refers to professional writer (of screenplays), in the discussions of financial issues such as rights and contracts.

${ }^{4}$ The Femis website lists 152 graduates in the scenario branch, including Noémie Lvovsky, Agnès de Sacy, Céline Sciamma, Thomas Caillé, Delphine Gleize and Rebecca Zlotowski.

5 'Producer films' are usually large budget mainstream productions opposed to art cinema because they originate from a commercial venture launched by a producer. The French also refer to orders ('films de commande'). The impact made by television and animation screenwriters is beyond the scope of this article, but their visibility is growing in the audiovisual economy. They are also trying to change the status and rights of authors in France. See feature article recently published in Télérama (Desplanques and Marzolf 2015) and Pierre Chevalier's report on the development of fiction. (Chevalier and al. 2011)

${ }^{6}$ See also Jeancolas, Meusy and Pinel, especially the chapter on the post-war period up to 1995 (1996 150-165) which discusses the successive institutional reforms of intellectual property rights in 1959 and 1985 and the evolution of the status of author for film directors. ${ }^{7}$ All translations of French quotations are by the author unless otherwise indicated.

${ }^{8}$ Bonnell's 2013 report follows amongst others 'Le droit des auteurs dans le domaine cinématographique: coûts, recettes et transparence' (Bonnell 2008); the SACD's report on authors' contracts, 'les contrats d'auteurs dans les longs-métrages' (in Dechesnes 2011); The the SAA's white paper 'Droits et rémunération des auteurs audiovisuels en Europe' (Despringre and Dormer 2011); and Pierre Chevalier's report 'Fiction française : le défi de l'écriture et de développement' (Chevalier, Philippon and Pialat 2011).

${ }^{9}$ There are indications that cinema on national television is no longer as popular as it was in the 1980s and 1990s. Canal+'s input also changing.
} 
${ }^{10}$ The credits list Nicolas Peufaillit and Abdel Raouf Dafri in addition to Thomas Bidegain and Audiard.

${ }^{11}$ Escande-Gauquié suggests that producers in 2010 usually have 10-12 projects in the pipeline at any given time, but only 1 in 4 is made and released in cinemas. $(2012,83)$

${ }^{12}$ For instance, the two authors who collaborated with Dany Boon on the script of Bienvenue chez les Ch'tis (2008), Franck Magnier and Alexandre Charlot (launched by les 'Guignols de l'info' TV programme in the 2000s), received a lump sum of $100000 €$ for their contribution of two and a half months, and rejected the $20 \%$ bonus from the producers. They failed to renegotiate any extra indexed on the film's box-office results. (See Boon's interview in Le Parisien reported on Purepeople website, 8 June 2008). http://www.purepeople.com/article/ dany-boon-je-suis-decu-par-1-attitude-des-scenaristes-des-ch-tis_a9939/1), accessed 12 July 2015. This film helped the progression of their careers: they went on to work on productions such as Astérix aux jeux Olympiques, before adapting and directing the comic strip Boule et Bill in 2013 (see Carrière 2008).

${ }^{13}$ In French, 'recettes nettes par producteur'. See guilde des scénaristes, http://www.guildedesscenaristes.org/uploads/ressbao/ accords/protocole_accord_transparence_filiere.pdf, accessed on 12 July 2015.

${ }^{14}$ The study is available online: 'Étude Les contrats d'auteurs dans les longs métrages', SACD, April-May 2011. http://www.sacd.fr/fileadmin/actualites/2011/opca cinema03052011 etude.pdf, accessed 12 July 2015.

15 See Jeancolas (1996, 150-165). The copyright laws changed in 1957 giving directors as well as screenwriters a share in the authorial rights. Until then, the legal (and financial) situation of directors had been unprotected. However, it was only in 1985, under Jack Lang, that directors saw significant changes implemented that protected their authorial status better. ${ }^{16}$ See Club des 13 2008, 97-102; Escande-Gauquié 2012, 93-97; Delorme 2015, 5.

${ }^{17}$ This is a recurring casual comment made by directors, actors and producers in many interviews, but statistics are not readily available to confirm more precisely.

18 '... accompagner un réalisateur et de travailler sur son territoire, sur son imaginaire'. (de Sacy in Sabaté 2013).

${ }^{19}$ See Lutaud (2013) who reports on Boon's earnings as actor, screenwriter, director and producer for his latest comedies. The writing budgets of films are available on the CNC website. For more examples, see the dossier published by Ecran total (Ganne and Siritzsky 2014) which provides breakdowns of screenwriters' earnings.

${ }^{20}$ Campillo has contributed to all his films since L'Emploi du Temps/Time Out in 2001 and Bidegain has co-written Un prophète (2009) De rouille et d'os/Rust and Bones (2012) and Deephan (2015) with Audiard.

${ }^{21}$ See Guilde website : "Protocole d'accord relatif à la transparence de la filière cinématographique", 2010.

http://www.guildedesscenaristes.org/uploads/ressbao/accords/protocole accord transparence filiere.pdf and "Protocole d'accord sur les pratiques contractuelles entre scénaristes et producteurs de fiction " 2012, http://www.guildedesscenaristes.org/uploads/ressbao/accords/accord scenaristes producteurs .pdf, both accessed on 2 April 2015.

${ }^{22}$ The SAA was created in 2010 on a European initiative. This description of their mission appears on their website. They published a report on audiovisual authors' rights and remuneration in Europe in 2011. (Despringre and Dormer 2011) 